\title{
PENGARUH FINANCIAL ATTITUDE, FINANCIAL KNOWLEDGE, PARENTAL INCOME TERHADAP FINANCIAL MANAGEMENT BEHAVIOR
}

\author{
Irine Herdjiono, Lady Angela Damanik \\ Universitas Musamus
}

E-mail: irene.herdjiono@gmail.com

\begin{abstract}
The aim of this research is to obtain the knowledge regarding the influence of Financial Attitude, Financial Knowledge, and Parental Income toward Financial Management Behavior. This research conducted in Merauke, border area of Indonesia. Questionnaire is used to collect the data.The sample 382 respondents. Correspondence analysis and chisquare are used to analyze.The result of this research show that Financial Attitude has influence toward Financial Management Behavior while Financial Knowledge and Parental Income have no influence toward Financial Management Behavior. This research has two implications, (1) attitude is an important factor in supporting financial behavior, where the attitude is generally influenced by environment and social interaction and (2) the financial knowledge has no influence on the financial behavior because financial education is less effective in low-medium income countries or regions.
\end{abstract}

Keywords: financial attitude, financial knowledge, parental income, financial management behavior. 


\section{PENDAHULUAN}

Perilaku keuangan (behavior finance) mulai dikenal dan berkembang didunia bisnis dan akademis pada tahun 1990. Berkembangnya behavior finance dipelopori oleh adanya perilaku seseorang dalam proses pengambilan keputusan (Ida dan Dwinta 2010). Perilaku keuangan haruslah mengarah pada perilaku keuangan yang bertanggungjawab sehingga seluruh keuangan baik individu maupun keluarga dapat dikelola dengan baik.

Perilaku keuangan masyarakat Indonesia yang cenderung konsumtif kemudian menimbulkan berbagai perilaku keuangan yang tidak bertanggungjawab lainnya seperti kurangnya kegiatan menabung, investasi, perencanaan dana darurat dan penganggaran dana untuk masa depan. Masyarakat Indonesia belum menabung secara maksimal. Di jajaran negara- negara Asia Tenggara pun, Indonesia menempati urutan terbawah dalam hal total nominal tabungan dan kebiasaan menabung. Otoritas Jasa Keuangan (OJK) mengatakan masyarakat Indonesia semakin konsumtif dan mulai meninggalkan kebiasaan menabung. Hal ini tercermin dari menurunnya marginal propensity to save (MPS) dalam 5 tahun terakhir dan naiknya marginal prosperity to consume (MPC).

Terdapat banyak penelitian terdahulu mengenai perilaku keuangan dengan berbagai variabel yang memengaruhinya. Berdasarkan penelitian yang dilakukan oleh Ida dan Dwinta (2010) menyatakan bahwa personal income tidak berpengaruh terhadap financial management behavior akan tetapi terdapat pengaruh financial knowledge terhadap financial management behavior.

Adapun penelitian yang dilakukan oleh Kholilah dan Iramani (2013), menunjukkan financial knowledge dan income tidak berpengaruh terhadap financial management behavior. Financial Knowledge tidak berpengaruh langsung terhadap Financial Management Behavior namun berpengaruh tidak langsung. Pengaruh Financial Knowledge terhadap Financial Management Behavior dimediasi oleh Locus of Control. Locus of Control tidak mampu memediasi pengaruh Income terhadap Financial Management Behavior. Penelitian yang dilakukan oleh Andrew dan Linawati (2014) menyatakan terdapat hubungan antara pengetahuan dan pendapatan dengan perilaku keuangan.

Penelitian yang dilakukan oleh Hilgert dan Hogarth (2003), menyatakan pengetahuan keuangan dan pendapatan terkait dengan praktek- praktek keuangan yang berkaitan dengan manajemen arus kas, manajemen kredit, tabungan, dan investasi. Berdasarkan penelitian yang dilakukan oleh Mien dan Thao (2015) yang dilakukan pada masyarakat Vietnam menyatakan bahwa sikap kevangan dan pengetahuan keuangan memiliki hubungan signifikan positif dengan perilaku manajemen keuangan.

Mahasiswa berada pada waktu yang sangat penting dalam kehidupan mereka dimana mereka menghadapi kemandirian financial dan mulai melakukan pengambilan keputusan yang bertanggung jawab (Elliehausen et al., 2007).

Variabel yang memengaruhi financial management behavior mahasiswa diantaranya financial attitude yang merupakan keadaan pikiran, pendapat serta penilaian tentang keuangan (Pankow, 2003). Hayhoe, et.al (1999) telah melaporkan bahwa ada hubungan antara financial attitudes dan tingkat masalah keuangan. Lim dan Teo (1997) memberikan 
bukti sejumlah financial attitudes juga terkait dengan kesulitan keuangan yang seringkali dihadapi oleh anak muda.

Variabel berikutnya yang juga memengaruhi financial management behavior ialah pengetahuan keuangan (financial knowledge). Edukasi mengenai tata kelola keuangan personal rupanya berdampak positif bagi mereka yang memiliki fasilitas keuangan seperti kartu kredit dan rekening di bank. Pemahaman mengenai cara mengelola dan merencanakan keuangan ini membuat 89 persen orang Indonesia merasa lebih optimistis menghadapi masa depan dengan kemandirian finansialnya.

Variabel lainnya yang memengaruhi perilaku keuangan juga dapat ditentukan oleh jumlah pendapatan orang tua mahasiswa. Pendapatan orang tua memengaruhi pengeluaran mahasiswa. Ipsos Public Affairs (2014) menyatakan orang tua berpendapatan lebih tinggi cenderung lebih banyak memberikan kontribusi pada pembayaran kuliah maupun tabungan anaknya.

\section{LANDASAN TEORI DAN PENGEMBANGAN HIPOTESIS Financial Management Behavior}

Financial management behavior adalah kemampuan seseorang dalam mengatur yaitu perencanaan, penganggaran, pemeriksaan, pengelolaan, pengendalian, pencarian dan penyimpanan dana keuangan sehari-hari (Kholilah dan Iramani, 2013). Munculnya financial management behavior, merupakan dampak dari besarnya hasrat seseorang untuk memenuhi kebutuhan hidupnya sesuai dengan tingkat pendapatan yang diperoleh (Kholilah dan Iramani, 2013).

Financial management behavior seseorang dapat dilihat dari empat hal (Dew dan Xiao, 2011) yaitu :

1. Consumption

Konsumsi, adalah pengeluaran oleh rumah tangga atas berbagai barang dan jasa (Mankiw, 2003). Financial management behavior seseorang dapat dilihat dari bagaimana ia melakukan kegiatan konsumsinya seperti apa yang di beli seseorang dan mengapa ia membelinya (Ida dan Dwinta,2010).

2. Cash-flow management

Arus kas adalah indikator utama dari kesehatan keuangan yaitu ukuran kemampuan seseorang untuk membayar segala biaya yang dimilikinya, manajemen arus kas yang baik adalah tindakan penyeimbangan, masukan uang tunai dan pengeluaran. Cash flow management dapat diukur dari apakah seseorang membayar tagihan tepat waktu, memperhatikan catatan atau bukti pembayaran dan membuat anggaran keuangan dan perencanaan masa depan (Hilgert dan Hogarth, 2003).

3. Saving and investment

Tabungan dapat didefinisikan sebagai bagian dari pendapatan yang tidak dikonsumsi dalam periode tertentu. Karena seseorangtidak tahuapa yang akan terjadidi masa depan, uang harusdisimpanuntuk membayarkejadian tak terduga.Investasi, yakni mengalokasikan atau menanamkan sumberdaya saat ini dengan tujuan mendapatkan manfaat di masa mendatang (Henry, 2009).

\section{Credit management}


Komponen terakhir dari financial management behavior adalah credit management atau manajemen utang. Manajemen utang adalah kemampuan seseorang dalam memanfaatkan utang agar tidak membuat anda mengalami kebangkrutan, atau dengan lain kata yaitu atau pemanfaatan utang untuk meningkatkan kesejahteraannya (Sina, 2014).

\section{Financial Attitude.}

Sikap mengacu pada bagaimana seseorang merasa tentang masalah keuangan pribadi, yang diukur dengan tanggapan atas sebuah pernyataan atau opini (Marsh, 2006). Pankow (2003), mendefinisikan financial attitudes sebagai keadaan pikiran, pendapat serta penilaian tentang keuangan.

Hayhoe, et.al (1999)menyatakan bahwa ada suatu hubungan antara financial attitudes dan tingkat masalah keuangan. Dengan demikian dapat dikatakan bahwa sikap keuangan seseorang juga berpengaruh terhadap cara seseorang mengatur perilaku keuangannya. Lim dan Teo (1997) dan Madern dan Schors (2012) menyatakan sejumlah financial attitudes juga terkait dengan kesulitan keuangan yang seringkali dihadapi oleh anak muda.

Financial attitudes dapat dicerminkan oleh enam konsep berikut (Furnham, 1984), yaitu:

1. Obsession, merujuk pada pola pikir seseorang tentang vang dan persepsinya tentang masa depan untuk mengelola vang dengan baik.

2. Power, yaitu merujuk pada seseorang yang menggunakan uang sebagai alat untuk mengendalikan orang lain dan menurutnya vang dapat menyelesaikan masalah.

3. Effort, merujuk pada seseorang yang merasa pantas memiliki uang dari apa yang sudah dikerjakannya.

4. Inadequacy, merujuk pada seseorang yang selalu merasa tidak cukup memiliki uang

5. Retention, merujuk pada seseorang yang memiliki kecenderungan tidak ingin menghabiskan uang

6. Security, merujuk pada pandangan seseorang yang sangat kuno tentang uang seperti anggapan bahwa vang lebih baik hanya disimpan sendiri tanpa ditabung di Bank atau untuk investasi.

\section{Financial Knowledge}

Pengetahuanmengacu pada apayang diketahui individu tentangmasalahkeuangan pribadi, yang diukur dengantingkat pengetahuanmereka tentangberbagai konsepkeuangan pribadi (Marsh, 2006). Financial knowledge, adalah penguasaan seseorang atas berbagai hal tentang dunia keuangan (Kholilah dan Iramani, 2013)

Pemudabelajar tentanguangsebagian besardari sekolahdan orang tua, dengan penekanan padapenghematan (Chowa et.al, 2012).Pada perkembangannya, pengetahuan mengenai keuangan mulai diperkenalkan diberbagai jenjang pendidikan.

Terdapat berbagai sumber pengetahuan yang dapat diperoleh, termasuk pendidikan formal,seperti program sekolah tinggi atau kuliah, seminar dan kelas pelatihan di luar sekolah, serta sumber-sumber informal, seperti dari orang tua, teman, dan lingkungan pekerjaan (Ida dan Dwinta, 2010). 
Untuk menangani personal finance secara sistematis dan berhasil maka diperlukan pengetahuan.Pengetahuan keuangan mempunyai hubungan yang erat dengan financial literacy atau edukasi keuangan. Hilgert dan Hogarth (2003), menyatakan bahwa financial knowledge sebagai definisi konseptual dari financial literacy.

Financial literacymenggambarkanprogram pendidikankeuangandengan mempelajari keterampilan tertentu sehingga individu memiliki kemampuan untuk mengendalikan masa depan keuangan mereka. Komponen financial literacy, didefinisikan sebagai kemampuan untuk membuat keputusan sederhana mengenai kontrak utang, khususnya bagaimana menerapkan pengetahuan dasar tentang bunga, diukur dalam konteks pilihan keuangan sehari-hari (Lusardi dan Tufano; 2008)

Menurut Chen dan Volpe (1998), literasi keuangan adalah pengetahuan untuk mengelola keuangan dalam pengambilan keputusan keuangan. Pengetahuan keuangan meliputi:

1. Pengetahuan umum keuangan pribadi

Kemampuan seseorang dalam mengelola aset keuangan pribadi. Dengan menerapkan cara mengelola keuangan yang benar maka seseorang akan mampu memanfaatkan uang yang dimilikinya untuk mencapai tujuan.

2. Tabungan dan pinjaman

3. Asuransi.

4. Investasi

\section{Parental income}

Nababan dan Sadalia (2012), menyatakan pendapatan orang tua adalah tingkat penghasilan yang diperoleh orang tua responden selama perbulan baik dari penerimaan gaji, upah, ataupun penerimaan dari hasil usaha

Menurut Badan Pusat Statistik (2013), tingkat pendapatan dapat dikelompokkan menjadi empat golongan yaitu:

a. Golongan sangat tinggi : lebih dari Rp. 3.500.000,00 per bulan

b. Golongan tinggi : Rp. 2.500.000,00 s/d Rp. 3.500.000,00

c. Golongan sedang : Rp. 1.500.000,00 s/d Rp. 2.400.000,00

d. Golongan rendah : kurang dari Rp. 1.500.000,00 per bulan

\section{Pengembangan Hipotesis}

\section{a. Pengaruh Financial Attitude terhadap Financial Management Behavior}

Sikap mengacu pada bagaimana seseorang merasa tentang masalah keuangan pribadi, yang diukur dengan tanggapan atas sebuah pernyataan atau opini (Marsh, 2006). Sementara, financial management behavior mengacu pada bagaimana seseorang berperilaku dalam kaitannya dengan hal keuangan pribadi,diukur dengan tindakan individu tersebut (Marsh, 2006).

Marsh (2006) menyatakan bahwa perilaku keuangan pribadi seseorang timbul dari sikap keuangannya, individu yang tidak bijaksana dalam menanggapi masalah keuangan pribadinya cenderung memiliki perilaku keuangan yang buruk. Menurut Furnham (1984), Sikap keuangan membentuk cara orang menghabiskan, menyimpan, menimbun, dan melakukan pemborosan uang. Sikap keuangan berpengaruh terhadap masalah 
keuangan seperti terjadinya tunggakan pembayaran tagihan dan kurangnya penghasilan untuk memenuhi kebutuhan. Pemikiran jangka pendek serta tidak adanya kemauan untuk menabung merupakan faktor-faktor sikap yang dapat menimbulkan masalah keuangan (Madern dan Schors, 2012)

Berdasarkan penjelasan diatas dapat dikatakan bahwa sikap kevangan memiliki pengaruh terhadap bagaimana seseorang mengatur perilaku keuangannya. Dengan demikian hipotesis pertama dalam penelitian ini adalah

\section{$\mathrm{H1}$ :Financial attitude berpengaruh terhadap financial management behavior}

\section{b. Pengaruh Financial Knowledge terhadapFinancial Management Behavior}

Pengetahuan mengacu pada apayang diketahui individu tentang masalah keuangan pribadi, yang diukur dengan tingkat pengetahuan mereka tentang berbagai konsep kevangan pribadi (Marsh, 2006). Pengetahuan seseorang tentang keuangan pribadi (melek finansial) berpengaruh pada perilaku keuangan (Sabri et al, 2008). Hung et al (2009), mengatakan seseorang dengan pengetahuan keuangan rendah cenderung tidak memahami masalah keuangan, kurang dalam melakukan perilaku keuangan yang baik dan kurang terampil dalam menghadapi guncangan ekonomi.

Financial knowledge tidak hanya mampu membuat seseorang menggunakan uang dengan bijak, namun juga dapat memberi manfaat pada ekonomi. Seseorangdengan pengetahuan finansial lebih tinggi mampu membuat keputusan yang baik bagi keluarga mereka dan dengan demikian berada dalam posisi untuk meningkatkan keamanan ekonomi dan kesejahteraan mereka, selain itu seseorang yang berpengetahuan keuangan yang membuat pilihan informasi sangat penting untuk sebuah pasar yang efektif dan efisien (Hilgert dan Hogarth, 2003).

Seseorang dengan financial knowledge akan lebih memahami masalah keuangan serta lebih baik dalam hal perilaku keuangannya. Sehingga,semakin baik pengetahuan tentang keuangan maka semakin baik pula seseorang dalam mengelola keuangannya. Oleh karena hipotesis kedua dalam penelitian ini adalah :

\section{H2 :financial knowledge berpengaruh terhadap financial management} behavior

\section{c. Pengaruh Parental Incometerhadap Financial Management Behavior}

Nababan dan Sadalia (2012), menyatakan bahwa pendapatan orang tua adalah tingkat penghasilan yang diperoleh orang tua responden selama perbulan baik dari penerimaan gaji, upah, ataupun penerimaan dari hasil usaha. income diukur berdasarkan pendapatan dari semua sumber. Komponen terbesar dari total pendapatan adalah upah dan gaji.

Selain itu Aizcorbe et al(2003), menemukan bahwa keluarga yang memiliki pendapatan yang lebih rendah memiliki kemungkinan yang lebih kecil untuk menabung.Pendapatan orang tua memengaruhi pengeluaran mahasiswa. Orang tua berpendapatan lebih tinggi cenderung lebih banyak memberikan kontribusi pada pembayaran kuliah maupun tabungan anaknya (Ipsos Public Affairs, 2014). Selain itu, terdapat kemungkinan yang lebih besar individu dengan sumber dana (income) yang tersedia akan menunjukkan perilaku manajemen keuangan yang lebih bertanggung jawab, mengingat dana (income) yang tersedia memberi mereka kesempatan untuk bertindak secara bertanggung jawab (Ida dan Dwinta, 2010). 
Berdasarkan uraian diatas menunjukkan bahwa orang tua dengan pendapatan yang lebih tinggi akan lebih mampu memberikan pendapatan kepada anaknya untuk membayar berbagai tagihan serta perilaku keuangan bertanggung jawab lainnya seperti menabung maupun investasi. Oleh karena hipotesis ketiga dalam penelitian ini adalah :

H3 :parental income berpengaruh terhadap financial management behavior

\section{METODE PENELITIAN}

\section{Sampel Penelitian}

Jumlah sampel sebanyak 382 orang mahasiswa di Merauke.

\section{Definisi Operasional Variabel Penelitian}

Penelitian ini menggunakan tiga variabel independen, dan satu variabel dependen. Adapun variabel dalam penelitian ini terdiri dari:

1. Financial attitude, adalah keadaan pikiran, pendapat serta penilaian tentang keuangan (Pankow; 2003). Indikator variabel ini dapat dilihat 6 konsep financial attitudes menurut Furnham (1984) yaitu obsession, power, retention, security, inadequancy, dan effort. Variabel Financial attitude data didapatkan dari jawaban responden terdapat 9 pertanyaandengan menggunakan skala Ordinal dengan sangat setuju (skor 1), setuju (2), ragu-ragu (3), Tidak Setuju (4), Sangat Tidak Setuju (skor 5).

2. Financial knowledge Menurut Chen dan Volpe (1998), pengetahuan keuangan adalah pengetahuan untuk mengelola keuangan dalam pengambilan keputusan keuangan. Indikator pengukurannya adalah sebagai berikut: pengetahuan umum keuangan pribadi, tabungan dan pinjaman, Asuransi, dan Investasi. Variabel financial knowledge didapatkan dari jawaban responden terhadap 12 pertanyaan. Kemudian jumlah jawaban yang benar dihitung dan dibagi dengan seluruh pertanyaan kemudian dikali seratus persen. Jawaban responden kemudian di bagi kedalam tiga kategori yaitu sebagai berikut, Tinggi $>80 \%$ dengan nilai 3 , Sedang $(60 \%<80 \%)$ dengan nilai 2 , dan Rendah $<60 \%$ dengan nilai 1 .

3. Parental income adalah pendapatan orang tua adalah tingkat penghasilan yang diperoleh orang tua responden selama perbulan baik dari penerimaan gaji, upah, ataupun penerimaan dari hasil usaha (Nababan dan Sadalia, 2012). Menurut Badan Pusat Statistik (2013) tingkat pendapatan dapat dikategorikan menjadi empat golongan yaitu:

Tabel 1. Tingkat Pendapatan

\begin{tabular}{lc}
\hline Golongan & Pendapatan per bulan \\
\hline Sangat tinggi & $>\operatorname{Rp~} 3.500 .000$ \\
Tinggi & Rp $2.500 .000 \mathrm{~s} / \mathrm{d}$ Rp 3.500 .000 \\
Sedang & Rp $1.500 .000 \mathrm{~s} / \mathrm{d} \mathrm{Rp} 2.400 .000$ \\
Rendah & $<$ Rp 1.500 .000 \\
\hline
\end{tabular}

Variabel dependen dalam penelitian ini adalah: financial management behavior. Financial management behavior seseorang dapat dilihat dari empat hal yaitu:consumption,cash-flow management,saving and investment, dan credit management. 
Dalam penelitian ini, responden ditanya mengenai seberapa sering mereka melakukan beberapa perilaku yang berkaitan dengan personal finance. Metode ini sejalan dengan penelitian sebelumnya (Xiao, et.al., 2007) dimana setiap pernyataan diberi skala ordinal dengan skor "tidak pernah" (skor 1), Sangat Jarang (skor 2), KadangKadang (skor 3), Sering (skor 4), "selalu" (skor 5).

\section{Analisis Korespondensi}

Analisis ini memberikan output berupa peta persepsi yang merupakan plot antara baris dan kolom dari matriks yang berbentuk data kategori. Menurut Yamin (2009) analisis korespondensi adalah metode analisis untuk melihat hubungan antara dua variabel nominal atau ordinal secara grafik yang dibentuk dalam ruang multidimensi dimana kategori yang bermiripan akan saling berdekatan. Analisis ini juga didesain untuk digunakan dalam pengembangan atau pengelompokan yang mewakili data frekuensi.

\section{Uji Chi-Square atau Kai Kuadrat}

Pengujian Hipotesis dalam penelitian ini menggunakan Uji Chi-Square (chi-kuadrat).

\section{HASIL DAN PEMBAHASAN}

Berdasarkan kuesioner yang berhasil dikumpulkan, karakteristik dan frekuensi jawaban responden dapat dilihat dalam tabel berikut ini:

\section{Tabel 2. Frekuensi Jawaban Responden}

\begin{tabular}{lcc}
\hline Frekuensi Jawaban Responden & Orang & Persen \\
\hline Financial Attitude : & 44 & 12 \\
Baik & 276 & 72 \\
Sedang & 62 & 16 \\
Buruk & $\mathbf{3 8 2}$ & $\mathbf{1 0 0 \%}$ \\
\hline Total & & \\
\hline Financial Knowledge : & 23 & 6 \\
Tinggi & 31 & 8 \\
Sedang & 328 & 86 \\
Rendah & $\mathbf{3 8 2}$ & $\mathbf{1 0 0 \%}$ \\
\hline Total & & \\
\hline Parental Income : & 70 & 18 \\
>Rp. 3.500.000 & 91 & 24 \\
Rp. 2.500.000 s/d Rp. 3.500.000 & 84 & 22 \\
Rp. 1.500.000 s/d Rp. 2.400.000 & 137 & 36 \\
< Rp. 1.500.000 & $\mathbf{3 8 2}$ & $\mathbf{1 0 0 \%}$ \\
\hline Total & & \\
\hline Financial Management Behavior : & 62 & 16 \\
Baik & 264 & 69 \\
Sedang & 56 & 15 \\
Buruk & $\mathbf{3 8 2}$ & $\mathbf{1 0 0 \%}$ \\
\hline Total & & \\
\hline
\end{tabular}

Sumber : Data di Olah 2016 
Dari Tabel2. dapat diketahui bahwa responden dengan tingkat financial attitude baik berjumlah 44 orang (12\%) dari keseluruhan jumlah sampel yang diteliti, sementara responden dengan tingkat financial attitude sedang merupakan jumlah terbanyak yaitu 276 orang $(72 \%)$ dari total keseluruhan responden dan responden yang berada pada tingkat financial attitude buruk berjumlah 62 orang (16\%) dari total keseluruhan responden yang diteliti.

Dilihat dari segi financial knowledge dapat diketahui bahwa dalam hal pengetahuan keuangan responden masih rendah, hal ini dapat terlihat dari jumlah responden terbanyak yang berada pada tingkat pengetahuan rendah yaitu sebanyak 328 orang (86\%) dari total seluruh responden. Dilihat dari segi tingkat pendapatan orang tua responden terbanyak adalah pendapatan orang tua kurang dari Rp. 1.500 .000 sebanyak 137 (36\%).

Tingkat financial management behavior responden terbanyak berada pada tingkat sedang yaitu $264(69 \%)$, responden yang memiliki financial management behavior baik berjumlah 62 orang (16\%) dan responden dengan tingkat financial management behavior buruk berjumlah 56 (15\%).

\section{Analisis Data}

\section{Kategorisasi Variabel}

\section{Financial Attitude}

Financial attitude dapat dikelompokkan menjadi tiga kategori yaitu buruk, sedang, dan baik untuk memudahkan pengamatan.Penentuan data menjadi tiga kategori dengan menggunakan metode kuartil.

Tabel 3. Tingkat Financial Attitude

\begin{tabular}{lll}
\hline Tingkat Financial Attitude & Nilai & Jumlah \\
\hline Baik & $\geq 3,80$ & 44 \\
Sedang & $2,66 \mathrm{~s} / \mathrm{d} 3,79$ & 276 \\
Rendah & $\leq 2,65$ & 62 \\
\hline Total & & $\mathbf{3 8 2}$ \\
\hline
\end{tabular}

Sumber : Data di Olah 2016

\section{Kategorisasi Financial Knowledge}

Financial Knowledge) dapat dikelompokkan menjadi tiga kategori yaitu rendah $(<60 \%)$, sedang $(60 \%<80 \%)$, dan tinggi $(>80 \%)$ untuk memudahkan pengamatan.

Tabel 4. Tingkat Financial Knowledge

\begin{tabular}{lll}
\hline Tingkat financial knowledge & Keterangan & Jumlah \\
\hline Tinggi & $>80 \%$ & 23 \\
Sedang & $60 \%<80 \%$ & 31 \\
Rendah & $<60 \%$ & 328 \\
\hline Total & & $\mathbf{3 8 2}$
\end{tabular}

Sumber : Data di Olah 2016

\section{Parental Income}

Berdasarkan hasil pengolahan data primer yang diperoleh dari penyebaran kuesioner dapat dilihat bahwa pendapatan orang tua responden terbanyak adalah pendapatan orang tua dengan golongan rendah ataukurang dari Rp. 1.500.000 sebanyak 137 orang atau $36 \%$, responden dengan pendapatan orang tua pada 
golongan tinggi antara Rp. 2.500 .000 s/d Rp. 3.500 .000 sebanyak 91 orang atau $24 \%$, responden dengan golongan sedang atau pendapatan orang tua antara Rp. 1.500.000 s/d Rp. 2.500 .000 berjumlah 84 orang atau $22 \%$ dan responden dengan pendapatan orang tua lebih dari Rp. 3.500 .000 berjumlah 70 orang atau $18 \%$ dari keseluran responden.

\section{Financial Management Behavior}

Tingkat perilaku keuangan (financial management behavior) dapat dikelompokkan menjadi tiga kategori yaitu buruk, sedang, dan baik untuk memudahkan pengamatan.Penentuan data menjadi tiga kategori dengan menggunakan metode kuartil.

Tabel 5. Tingkat Financial Management Behavior

\begin{tabular}{lll}
\hline Financial Management Behavior & Keterangan & Jumlah \\
\hline Baik & $\geq 3,99$ & 62 \\
Sedang & $2,49 \mathrm{~s} / \mathrm{d} 3,98$ & 264 \\
Buruk & $\leq 2,48$ & 56 \\
\hline Total & & $\mathbf{3 8 2}$ \\
\hline
\end{tabular}

Sumber : Data di Olah 2016

\section{Analisis Korespondensi}

Analisis korespondensi adalah metode analisis untuk melihat hubungan antara dua variabel nominal atau ordinal secara grafik yang dibentuk dalam ruang multidimensi dimana kategori yang bermiripan akan saling berdekatan.

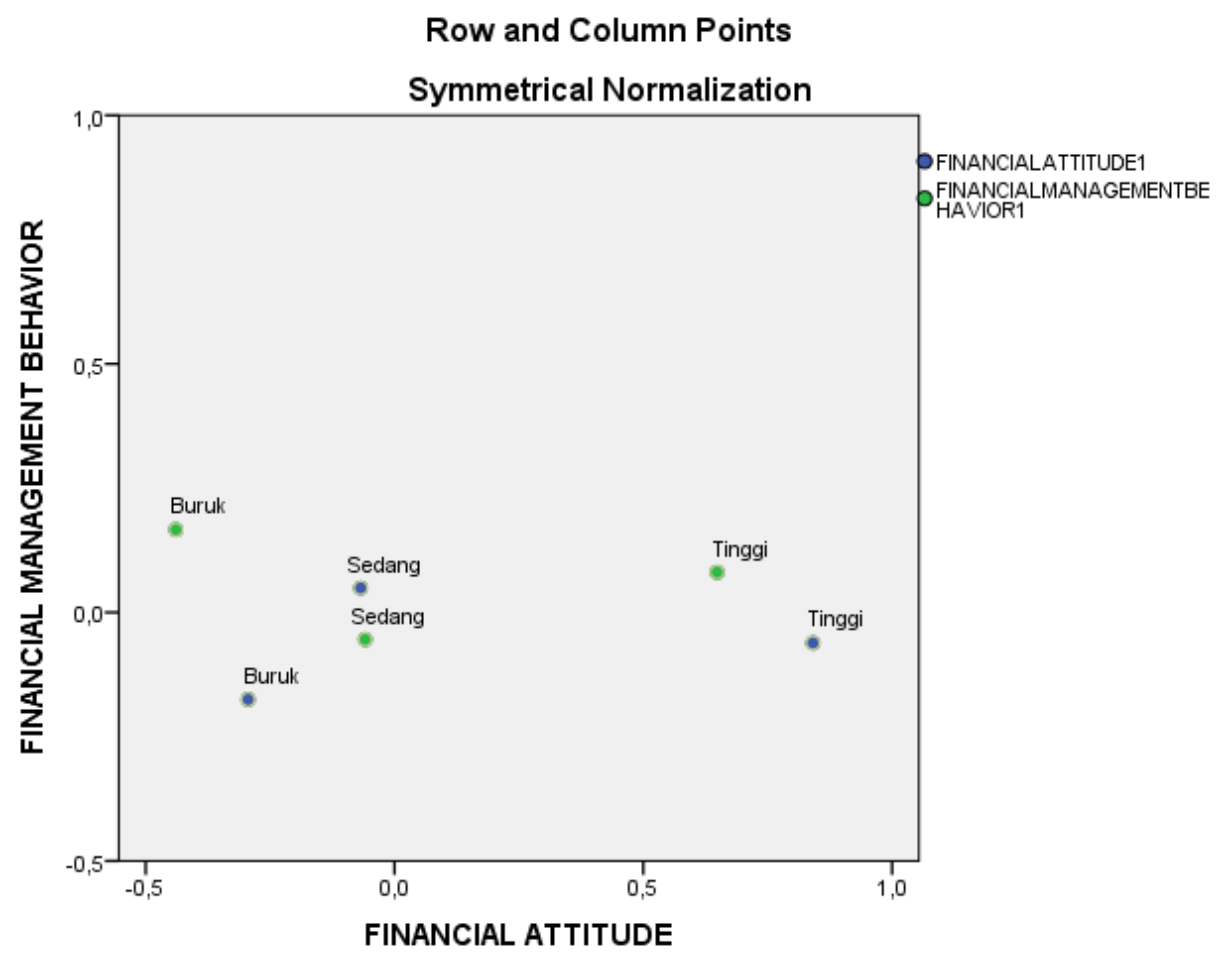

Gambar 1.Analisis Korespondensi Financial Attitude Terhadap Financial Management Behavior

Sumber : Data di Olah 2016 
Berdasarkan Gambar 1. terlihat bahwa titik financial attitude 1 atau buruk berdekatan dengan financial management behavior 1 atau buruk menunjukkan bahwa mahasiswa dengan financial attitude buruk juga memiliki financial management behavior buruk begitupun pada mahasiswa dengan financial attitude sedang memiliki financial management behavior sedang dan mahasiswa dengan financial attitude baik memiliki financial management behavior baik.

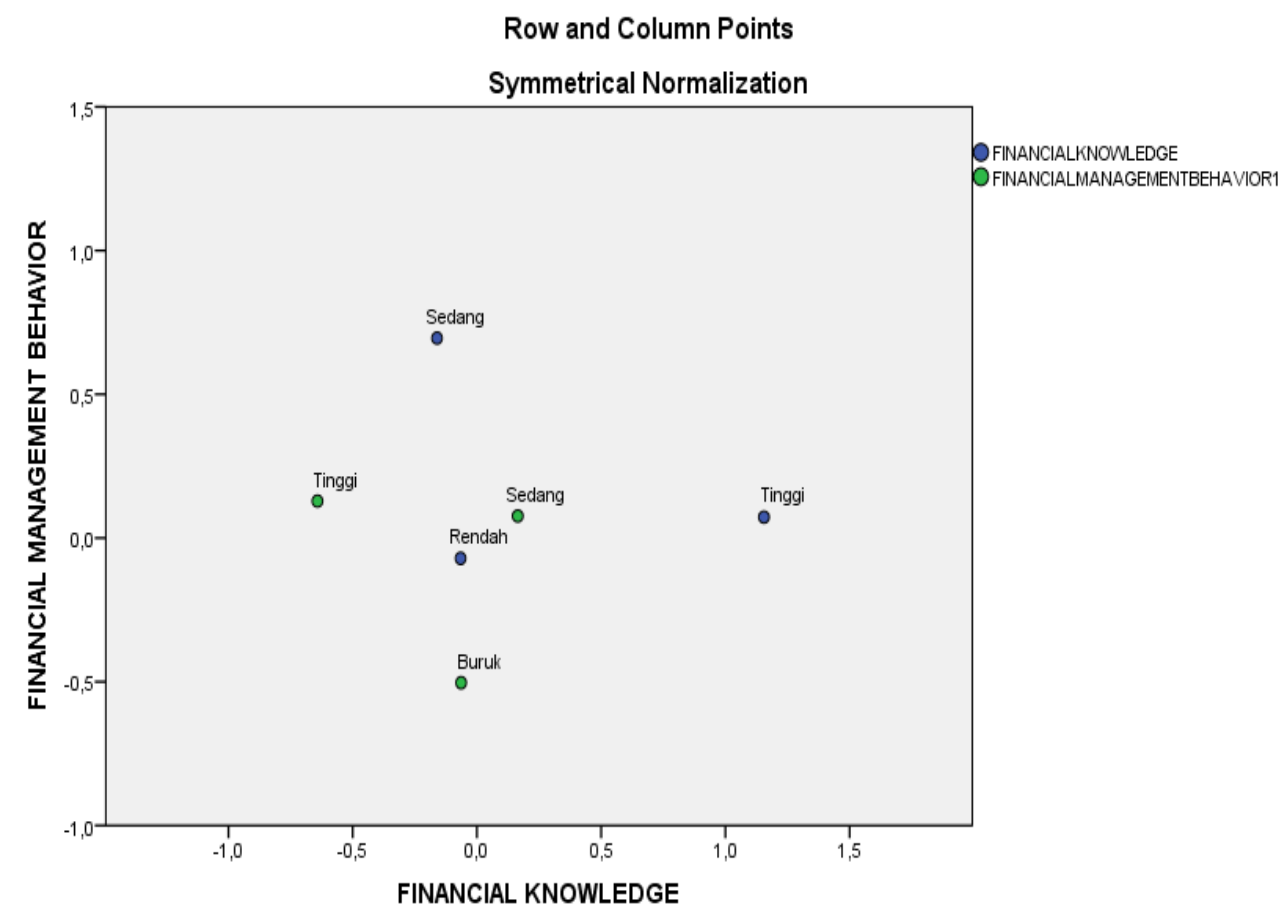

Gambar 2.Analisis Korespondensi Financial Knowledge Terhadap Financial Management Behavior

Sumber : Data di Olah 2016

Berdasarkan Gambar 2. terlihat bahwa letak titik tidak berdekatan antara financial knowledge rendah dan financial management behavior rendah demikian pula pada sedang dan tinggi. Dengan demikian dapat disimpulkan tidak terdapat kemiripan kategori antara financial knowledge dan financial management behavior. 


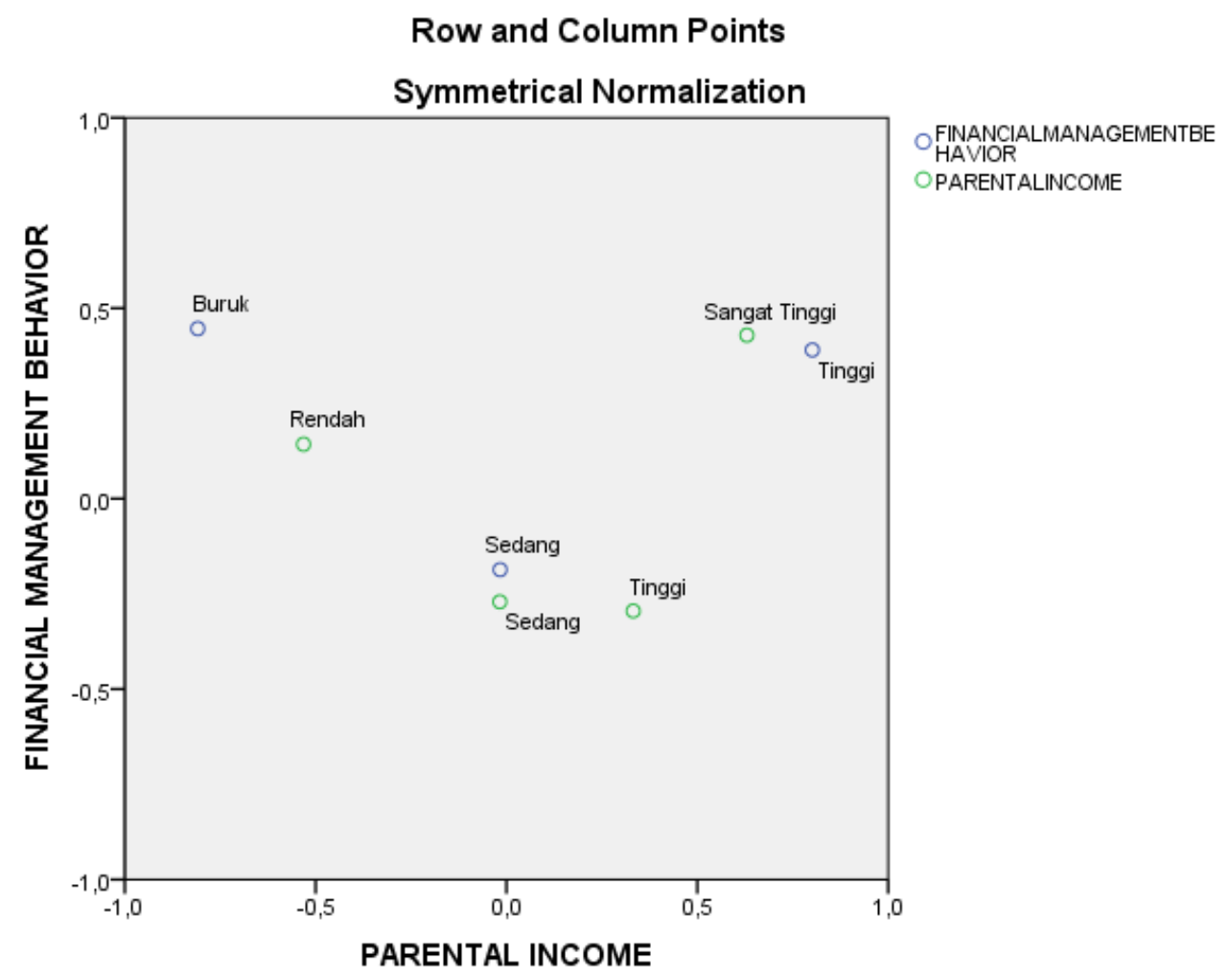

\section{Gambar 3.Analisis Korespondensi Parental Income Terhadap Financial Management Behavior}

Sumber : Data di Olah 2016

Berdasarkan Gambar 3. terlihat bahwa letak titik tidak berdekatan antara parental income rendah dan financial management behavior rendah demikian pula tingkat tinggi hanya tingkat sedang yang berdekatan yang menunjukan tidak adanya keterkaitan antara kedua variabel tersebut.

\section{Uji Chi-Square atau Chi-Kuadrat}

Hasil Perhitungan Chi-Square dapat dilihat pada Tabel 6 berikut:

Tabel 6. Hasil Analisis Chi-Square

\begin{tabular}{lcc}
\hline \multicolumn{1}{c}{ Variabel } & Chi square & Sig \\
\hline Financial attitude & 1210,031 & 0,001 \\
Financial knowledge & 82,957 & 0,329 \\
Parental income & 118,175 & 0,452 \\
\hline
\end{tabular}

Sumber : Data di Olah 2016

\section{Pembahasan}

Pengaruh Financial Attitude terhadap Financial Management Behavior

Terdapat pengaruh antara financial attitude dengan financial management behavior karena nilai signifikan pada uji chi square sebesar 0,001 lebih kecil dari 0,05. Mahasiswa dengan sikap keuangan yang lebih baik cenderung lebih bijak perilaku keuangannya bila di bandingkan dengan mahasiswa pada tingkat sikap keuangan yang buruk. 
Sikap keuangan berpengaruh dalam menentukan perilaku keuangan seseorang. Sikap keuangan mengarahkan seseorang dalam mengatur berbagai perilaku keuangannya. Dengan sikap keuangan yang baik maka seseorang akan lebih baik pula dalam pengambilan berbagai keputusan terkait manajemen keuangannya.

Seseorang dengan tingkat financial attitude baik akan menunjukan pola pikir yang baik tentang vang yaitu persepsinya tentang masa depan (obsesion), tidak menggunakan uang untuk tujuan mengendalikan orang lain atau sebagai penyelesai masalah (power), mampu mengontrol situasi keuangan yang dimiliki(effort), menyesuaikan penggunaan uang sehingga mampu mencukupi kebutuhan hidupnya (inadequancy), tidak ingin menghabiskan vang (retention), dan memiliki pandangan yang selalu berkembang tentang vang atau tidak berpandangan kuno (securities) sehingga akan mampu melakukan kontrol terhadap konsumsinya, mampu menyeimbangkan pengeluaran dan pemasukan yang dimiliki (cash flow), menyisihkan uang untuk tabungan dan investasi, serta mengelola hutang yang dimiliki untuk kesejahteraannya.

Hasil penelitian ini sejalan dengan penelitian yang dilakukan oleh Mien dan Thao(2015) terdapat hubungan yang signifikan antara sikap keuangan seseorang akan cenderung memiliki perilaku keuangan yang lebih bijak.

\section{Pengaruh Financial Knowledge terhadap Financial Management Behavior}

Hasil uji hipotesis financial knowledge tidak berpengaruhterhadap financial management behavior, karena nilai chi square 0,329 lebih besar dari 0.05.Tidak terbukti bahwa seseorang dengan pengetahuan keuangan tinggi memiliki perilaku keuangan baik maupun seseorang dengan financial knowledge rendah memiliki financial management behavior yang buruk.

Financial management behavior seseorang dapat dipengaruhi oleh berbagai faktor. Pengetahuan seseorang terhadap keuangan cenderung berbeda, akan tetapi tidak selamanya seseorang dengan pengetahuan keuangan tinggi mampu mengendalikan manajemen perilaku keuangannya.

Faktor-faktor lain yang dapat mempengaruhi perilaku keuangan adalah lingkungan, pergaulan dan cara bersosialiasi, kontrol dari orang tua, faktor kebiasaan, locus of control (Joo et al., 2003), perilaku impulsif,kepuasan hidup, stress (Norvilitis dan Maria, 2002), sosialisi orang tua (Palmer et al,2001), materialisme (Pinto et al, 2000) dan faktor-faktor psikologis yang sulit diukur dan tidak dimasukkan dalam penelitian ini.

Kecenderungan responden mempraktekkan financial management behavior yang diharapkan tidak meningkat secara konsisten seiring dengan peningkatan financial knowledge. Hal ini disebabkan perilaku seseorang tidak selalu dipengaruhi tingkat pengetahuan yang dimilikinya, tetapi juga dipengaruhi oleh faktor-faktor lain seperti faktor psikologis dan emosi (Nababan dan Sadalia, 2012).

Hasil penelitian ini sejalan dengan Kholilah dan Iramani(2013), Nababan dan Sadalia (2012), bahwa financial knowledge tidak memiliki pengaruh yang signifikan terhadap perilaku kevangan mahasiswa.Kaiser dan Menkhoff (2016) menyimpulkan bahwa financial education di negara dengan pendapatan yang rendah dan menengah kurang efektif sehingga tidak mempengaruhi perilaku keuangan. 


\section{Pengaruh Parental Income terhadap Financial Management Behavior}

Hasil uji hipotesis dengan chi-square parental income atau pendapatan orang tua tidak berpengaruh terhadap financial management behavior, karena nilai chi square 0,452 lebih besar dari 0,05.

Hasil penelitian parental income yang tidak berpengaruh terhadap financial management behavior dapat dikaitkan dengan perbedaan distribusi jumlah vang yang diberikan oleh masing-masing orangtua kepada anaknya. Tidak berarti orangtua dengan pendapatan lebih tinggi akan memberikan vang dengan jumlah lebih tinggi kepada anaknya untuk berbagai kebutuhan anak.

Hasil penelitian ini sejalan dengan penelitian Mayer (2002) yang menyatakan bahwa ratarata distribusikenaikan keseluruhan 10 persen pendapatan pada orang tua baik upah, laba, dan pendapatan hanya berdistribusi peningkatan pendapatananak tidak lebih dari 2 persen, dan mungkin kurang. Ini mengindikasikan bahwa tingginya pendapatan orang tua tidak berpengaruh pada pendapatan seorang anak. Rendahnya tingkat distribusi pendapatan orang tua kepada anaknya menyebabkan dana yang dimiliki anak untuk berbagai kegiatan keuangannya seperti kegiatan konsumsi, menyeimbangkan pengeluaran dan pemasukan (cash flow), serta menabung dan investasi relatif tetap walaupun pendapatan orangtua tinggi. Kecilnya distribusi pendapatan orangtua pada anak menyebabkan ketersediaan dana pada mahasiswa relatif tidak berbeda, sehingga perilaku keuangan mahasiswa cenderung sama walaupun tingkat pendapatan orang tua berbeda.Hasil penelitian ini juga sejalan dengan penelitian Nababan dan Sadalia (2012) bahwa pendapatan orang tua tidak berpengaruh signifikan pada perilaku keuangan.

\section{SIMPULAN}

Berdasarkan penelitian dan pembahasan yang dilakukan diatas dapat ditarik kesimpulan sebagai berikut:

1. Sikap keuangan (Financial Attitude) berpengaruh terhadap financial management behavior.

2. Pengetahuan Keuangan (Financial Knowledge) tidak berpengaruh terhadap financial management behavior.

3. Parental income tidak berpengaruh terhadapfinancial management behavior mahasiswa. Hasil ini dikaitkan dengan rendahnya tingkat distribusi pendapatan orang tua kepada anak yang menyebabkan jumlah dana yang dimiliki mahasiswa relatif sama sehingga financial management behavior punrelatif sama.

\section{SARAN}

Beberapa saran perlu diberikan terkait dengan penelitian dan hasil yang telah dicapai

1. Mahasiswa perlu mendapatkan pelatihan terkait bagaimana financial attitude yang baik karena financial attitude memiliki pengaruh terhadap financial management behavior.

2. Penelitian selanjutnya dapat memasukkan variabel lain atau variabel moderasi yang secara teoritis berpengaruh terhadap Financial Management Behavior seperti faktorpsikologis, emosi, lingkungan, sosialisasi orang tua, locus of control, perilaku impulsif, kepuasan hidup, dan stres. 


\section{DAFTAR PUSTAKA}

Aizcorbe, Ana M., Arthur B. Kennickeell,dan Kevin B.Moore.2003. Recent Changes in U.S. FamilyFinances:Evidence from the 1998 and 2001 Survey of Consumer Finances.Federal Reserve Bulletin, 89: 1-32.

Andrew Vincentius, Linawati Nanik.2014. Hubungan Faktor Demografi dan Pengetahuan Keuangan, dengan Perilaku Keuangan Karyawan Swasta di Surabaya, FINESTA Vol. 02, No. 02:35-39

Chowa, Gina A.N., DespardMat, dan Akotolsaac Osei. 2012. Financial Knowledge and Attitudes of Youth in Ghana.YouthSave Research Brief.

Chen, H. dan Volpe, R. P. 1998.An analysis of personal financial literacy among college students.Financial services review, 7(2): 107128

Dew, Jeffery., Xiao Jing Jian. 2011. The Financial Management Behavior Scale: Development and Validation. Journal of Financial Counseling and Planning Volume 22: 43-59.

Elliehausen, Gregory, E. Christopher Lundquist, and Michael E. Staten, 2007. The Impact of Credit Counseling on Subsequent Borrower Behavior. Journal of Consumer Affairs, 41 (1), $1-28$.

Furnham, A.1984. Many Sides of the Coin: The Psychology of Money Usage. Personality and Individual Differences, 5: 501:509.

Hayhoe, C.R., Leach, L., danTurner, P. R. 1999. Discrimining the Number of Credit Cards Held by College Students Using Credit Card and Money Attitudes. Journal of Economic Psychology, 20: 643-656.

Henry Faizal Noor 2009. Investasi, Pengelolaan Keuangan Bisnis, dan Pengembangan Ekonomi Masyarakat,Jakarta: Indeks.

Hilgert,Marianne A., Jeanne M.Hogarth dan Sondra Baverly.2003. Household Financial Management : The Connection between Knowledge and Behavior.Federal Reserve Bulletin,89(7):309-322.

Hung Angela A., Parker Andrew .M, Yoong Joanne K 2009. Defining and Measuring Financial Literacy.Labor And Population Working Paper.

Ida dan Chintia Yohana Dwinta.2010. Pengaruh locus of control, financial knowledge, dan income terhadap financial management behavior. JurnalBisnis dan Akuntansi, Vol. 12, No. 3: 131 - 144.

Ipsos Public Affairs. 2014. How America Pays for College. Sallie Mae's National Study of College Students and Parents

Joo, S. H., Grable, J. E., dan Bagwell, D. C. 2003. Credit card attitudes and behaviors of college students. College Student Journal, 37(3), 405-419.

Kaiser, Tim dan Lukas Menkhoff. 2016. Does Financial Education Impact Financial Behavior, and If so, When?.Discussion Papers of DIW Berlin

Kholilah Naila Al, Iramani Rr . 2013. Studi Financial Management Behavior pada Masyarakat Surabaya,Journal of Business and Banking Volume 3, No. 1: $69-80$

Lim, V. K. G., danTeo, T. S. H. 1997. Sex, Money and Financial Hardship: An Empirical Study of Attitudes Towards Money Among Undergraduates in Singapore. Journal of Economic Psychology, 18, 369-386

Lusardi, A., Tufano, P. 2008. Debt literacy, financial experiences, and overindebtedness. Dartmouth Working Paper.

Madern, Tamara, Schors Anna Van Der. 2012.Financial attitudes and skills as early-warning signs of financial problems.Dutch National Institute for Family Finance Information. 
Marsh, Brent A.2006.Examining the personal finanial attitudes, behavior and knowledge levels of first-year and senior students at BaptistUniversities in the State of Texas. Bowling Green State University

Mankiw, N Gregory .2003. Pengantar Ekonomi, Edisi ke-2 Jilid 2, Jakarta:Erlangga.

Mayer Susan E.2002.The Influence of Parental Incomeon Children's Outcomes. Knowledge Management Group, Ministry of Social Development, Te Manatu Whakahiato Ora.

Mien Nguyen Thi Ngoc,Thao Thran Puong. 2015. Factors Affecting Personal Financial Management Behaviors : Evidence from Vietnam.Proceedings of the Second AsiaPacific Conference on Global Business, Economics, Finance and Social Sciences (AP15Vietnam Conference).

Nababan Darma dan Isfenti Sadalia. 2013. Analisis Personal Financial Literacy dan Financial Behavior Mahasiswa strata I Fakultas Ekonomi Universitas Sumatera utara. Media Informasi Manajemen Vol 1 No.1:1-16.

Norvilitis, J. M., dan Maria, P. S. 2002. Credit card debt on college campuses: Causes, consequences and solutions. College Student Journal, 36(3), 357-364.

Palmer, T. S., Pinto, M. B., \& Parente, D. H. 2001. College students' credit card debt and the role of parental involvement: Implications for public policy. Journal of Public Policy \& Marketing, 20(1), 105-113.

Pankow, Debra 2003. Financial, Values, Attitudes and Goals, North Dakota State University Fargo, North Dakota 58105.

Pinto, M. B., Parente, D. H., \& Palmer, T. S. 2000. Materialism and credit card use by college students. Psychological Reports, 86, 643-652.

Sabri Mohamad Fazli, MacDonald Maurice, Masud Jariah, Paim Laily, Hira Tahira K., Othman Mohd. Amim 2008.Financial Behavior and Problems among College Students in Malaysia: Research and Education Implication. Consumer Interests Annual Volume 54:166-170.

Sina, Peter Garlans.2014. Tipe Kepribadian Dalam Personal Finance. Jurnal JIBEKA Volume 8 No $1: 54-59$.

Xiao, J. J., Shim, S., Barber, B., \& Lyons, A. 2007. Financial behavior and quality of life of college students: Implications for college financial education. Proceedings of Association for Financial Counseling and Planning Education: 33-43.

Yamin, sofyan dan Heri kurniawan. 2009. SPSS COMPLETE: Teknik Analisis Statistik Terlengkap dengan Software SPS. Jakarta: Salemba Infotek. 